\title{
Petrology of Spinel Peridotite Xenoliths from Cenozoic Basaltoids in the Khanka Craton's Terrain (East Russia)
}

\author{
Prikhodko, V.S. and Zemlyanukhin. V.N.
}

Institute for Tectonics and Geophysics, Khabarovsk 680063, Russia

In the eastern flank of the Central Asian fold belt there outcrop a number of big craton's terrains (Khankaisk. Bureinsk. etc.) the basis of which is made up by fragments of Precambrian crystalline complexes separated by younger fold structures. Within the Khanka craton's terrain Cenozoic alkaline basaltoids containing spinel peridotite xenoliths are widespread. The upper mantle under Precambrian complexes is represented by spinel peridotite xenoliths from the Kirovsk and Medvezhy volcanic structures, and the mantle near the margin of the Precambrian block with the Early Paleozoic fold system - deep rock nodules from the Sviyaginsk volcano.

Nodules are mainly represented by spinel lherzolites. more rarely harzburgites and websterites occur. Xenoliths with relatively uniform distribution of all the minerals with the grain sizes from 0.5 $106 \mathrm{~mm}$ prevail. The traces of residual high-temperature plastic deformations are constantly ohserved. The level of ordering of microstructural olivine patterns increases from fine-grained wirds coarse-grained varieties and from xenoliths of the Kirovsk and Medvezhy volcanoes to the Sijyaginsk volcano. For the Sviyaginsk volcano xenoliths the prevailing mechanism of plastic deformations was the intracrystal slide, and for the deep rocks of two other structures - dynamic recrystallization together with the slide.

Based on petrochemical and geochemical criteria. xenoliths of the Sviyaginsk volcano are similar to the "primitive" mantle material. while xenoliths from the other two structures are considerably more depleted. Olivines are characterized by narrow limits of $\mathrm{MgO}$ and $\mathrm{FeO}$ variations, while pyroxenes and chrome-spinellids from the nodules are characterized by wide variations of many elements. Among venoliths of the Kirorsk and Medvezhy volcanoes there occur the least aluminous varieties of these minerals.

Analysis of the cation exchange between olivines, ortho-clinopyroxenes and chromespinellids in the vivigansk volcano xenoliths showed that together with the increase of a degree of rock kformation silicates get enriched in magnesium. spinel - in iron. and clinopyroxenes get depleted in jadeite minal and spinels get enriched in chromium. In the same direction the temperature of deep rock mineral parageneses balance decreases. In xenoliths of the volcanoes draining the upper mantle under Precambrian blocks no correlation between the mineral grain sizes, the degree of deformation and the above mentioned material parameters has been found.

Thus. within the Khankaisk craton's terrain. spinel peridotite xenoliths characterizing the upper mante of the Nakhimovsk Precambrian block are the most deformed and depleted ones. It appears that the most wide-scale mantle processes took place in the Precambrian. Further evolution of the upper mantle material of the craton considered is characterized by the transition from the cool depleted lithosphere to the mantle with increased thermal regime. 